\title{
On Heroes and She-roes: Self-Esteem and Breaking the Cycle of Prison Recidivism Ed Poindexter
}

$\mathrm{I}^{\mathrm{entim}}$ enjoy looking up words in the dictionary to learn their root meaning. In the old days people knew exactly what they were doing when they assigned names and labels to things, places, events, and states of mind. "Esteem," for example, stems from the Latin word aestimare, and means to appraise, estimate, or give an opinion of. Therefore, self-esteem is the appraisal, estimation, or opinion we have of ourselves. It is a common belief that people with high self-esteem produce good results, and that those with low self-esteem produce poor results.

The term is sometimes used interchangeably with self-image, which is the mental picture we have of ourselves. Our thoughts and behaviors are reflections of our self-image. Self-confidence is assurance we have in our abilities. Often confused with conceit, self-love is a prerequisite to truly loving others. Conceit is actually a mask or facade worn to hide such insecurities as an inferiority complex. To fall in love with someone with little or no self-love is asking for trouble.

Technically, self-esteem is our opinion of our self-love, self-image and self-confidence. They are so closely related that if one is low the others will sag. Also used interchangeably with self-esteem, self-concept is the sum total of all the above.

I have become so preoccupied with these terms over the past ten years that I am convinced people with high self-esteem either do not come to prison, or do but learn from their mistakes, leave, and never return. Those with high self-esteem do not lead perfect lives, but they do tend to adapt well to their environments, find meaning in their lives, are resilient, and are equipped with coping and other skills that enable them to wade through life's problems, challenges and stumbling blocks, while maintaining their sanity and peace of mind.

I did not always believe this. And it was not until ten years ago that I had even heard of the terms. I more or less evolved into this belief. To explain the hows and whys of my evolution I must begin with the selection of my life's heroes and she-roes, for they have represented the various stages of my intellectual, emotional, and spiritual growth. 
My early childhood heroes and role models were my three uncles: Bob, Bill, and Irvin. Their influence in my life became stronger following the accidental drowning of my father when I was eight years old. As a pre-teen my heroes were George Washington Carver; superstar athletes Harrison Dillard and Jesse Owens, Ollie Matson, and later Jim Brown; and superstar entertainers Chuck Berry, Fats Domino, Little Richard, Big Mama Thornton, Muddy Waters, and Howlin' Wolf. I was especially drawn to the blues because it was a musical balm for nearly all my ailments. But like many balms, it did not always heal and something stronger was required.

After a few years of military service I began to idolize writers James Baldwin, Langston Hughes and Claude McKay; musicians Charlie Parker, Wes Montgomery, Miles Davis, John Coltrane, and Cannonball Adderly; and singers Billy Holiday, Nancy Wilson, Nina Simone, and Odetta. I was especially fond of how writers manipulated and shaped words to tug at the reader's heart and conscience. By writing about things I had knowledge of and/or personal experience with, these writers spoke for me until I learned to transfer my own thoughts, feelings, and experiences to paper.

Toward the middle of my six and a half years of military service my heroes began to reflect my rebellious nature asserting itself. That indescribable angst inside me yearned for expression, to be heard, to be addressed, and healed. This was when Malcolm X, Dr. Martin Luther King Jr., Muhammad Ali, and Mahatma Gandhi spoke for me.

By the time I returned to civilian life in the fall of 1968, America's cultural revolution, spearheaded by the black consciousness movement, was in full swing. No longer did I idolize athletes, but instead great thinkers who reflected that era: Amilcar Cabral, Ho Chi Minh, Mao Tse Tung, Huey P. Newton, Eldridge Cleaver, Che Guevera, Fidel Castro, Regis Dubray, Jomo Kenyatta, Patrice Lumumba, and Julius Nyrere. My selection of these heroes culminated in my enlistment into the Black Panther Party where, for one of the few times in my life, I felt genuinely useful and connected to something meaningful and greater than myself.

On August 29, 1970, my mother was the only hero (in this case, she-ro) qualified to hold that coveted title when she cradled my year-old niece Ericka and stood calmly but defiantly inside the doorway of our home and told a battalion of arresting officers, "If you have to arrest him, do so. But if you shoot him, you're going to have to shoot through me and this baby first!" That is the kind of stuff my mother is made of. 
By time I was sent to prison in the spring of the following year (by way of railroad express), heroes Frantz Fanon, Dick Gregory, George Jackson, and she-ro Angela Davis cloaked around my wounded but still intact social and political conscience. During this era I was referred to as a "political prisoner of conscience," a "black revolutionary Marxist"-labels I now reject. Just plain Ed Poindexter will suffice.

It was a time of segregated rat- and roach-infested cell halls, and breakfast cereal laced with ants and maggots. Where mush, a boiled potato, a spoonful of green beans, a cup of lukewarm water, and a stale slice of white bread were the daily menu in solitary confinement. On more than one occasion I was beset by the misfortune of dining on said dubious delicacies.

My fall partner (then known as David L. Rice, now known as Mondo we Langa) and I were not allowed to participate in the education program because the school's principal was resentful of our political views. Her narrow mind even prohibited black oriented publications as innocuous as Ebony and Jet from entering the prison. I do not believe she was a racist, just dumb as hell. How an alleged survivor of a Nazi concentration camp could be so cruel and heartless, I will never understand.

When the donated magazines arrived she threw them into the trash, but they were retrieved by prisoner janitors and circulated around the prison. I remember silently complaining that by time Jet got around to me, the centerfolds had been extracted. But I did not dare let that out, because such a black revolutionary Marxist political prisoner of conscience as myself was not supposed to find such exploitative objectification of women appealing. Truth is, I did then, and still do. But that is another story.

And that was how we got to read Ebony and Jet magazines from 1971 through 1974. (Yes, I have been in prison for nearly thirty straight calendar years.) The principal was eventually expelled from her corrections perch when results of an investigative report revealed she was maintaining a harem of prisoner clerk sex slaves, and had fraudulently filed her employment application of more than twenty years earlier. (I have not yet decided which was worse.) She claimed to have been awarded several advanced academic letters, an M.A. and a Ph.D. As it turned out, she was a mere high school graduate. To my distorted way of thinking, that the system could have hired such a character as the woman principal was proof positive that all appointed and elected officials and functionaries were equally as corrupt and hypocritical as she was. Therefore, we were all classified as "political prisoners," mere 
victims caught in the system's sticky web of economic, sexual, and political oppression, and should not be held accountable for our crimes. Flip Wilson once said, while donning his Geraldine facade, "The devil made me do it." In this case, the "system" made us do it, so we should have been either exempt from punishment altogether or received a reduction of sentence for those carrying the Punishment Discount Card.

Like most other left-wing radicals and black revolutionaries of the time, I made political excuses for every type of criminal imaginable, which was made easy when considering the escapades of such people as the principal. For example, bank robbery was justified and explained away by the "fact" that banks are instruments of the corrupt establishment that help keep the poor and oppressed masses shackled in economic bondage. Ripping them off was an act of "revolutionary love," especially if the spoils were distributed among the "poor and oppressed masses." Outlaws among the oppressed masses were the real Robin Hoods.

If a man served time for domestic assault, his actions could not possibly have been any worse than the assaults the masses were daily subjected to at the hands of the "racist, fascist pigs" of the power structure, or when some desperately poor Third World country was besieged by the "barbaric, imperialist U.S. military machine." Assaults of all types were mere manifestations of stress resulting from the intense psychological tyranny visited upon the oppressed and downtrodden masses by said government establishment.

Of course, burglars stole from the "haves," but hocked the booty for food with which to feed their starving children. Alcohol and drug addiction were more signs that the tyranny of racism, political and economic oppression were literally driving the hapless masses mad. No matter what the problem or crime was, the "system" was always at fault, and only the system could fix it. Of course the system either could not or would not fix it, therefore the oppressed masses needed to wage "revolutionary armed struggle" against the U.S. government.

In 1974 my partner and I were finally allowed to participate in the prison's educational programs, and enrolled in most of the college courses offered. I was engaged in a desperate, insatiable thirst for learning and welcomed any challenge that would foster my emotional, intellectual, and spiritual growth. I was eventually hired as one of the new principal's clerks (don't even go there), and enjoyed working around people who acted like they had some 
sense. The education environment proved good for me, and within a few years I had accrued over a hundred college credits from three different schools, and even worked on a six-by-twenty-foot mural containing a bicentennial theme. I collaborated with a school instructor on a selfenrichment class that applied self-hypnosis techniques to relaxation and stress management, then later with a community volunteer on applying hatha and raja yoga (the physical exercises and mental exercises) to the same ends.

The school became my haven, a refuge from the relentless madness that saturated the rest of the prison population and held it in a death grip of perpetual turmoil. But it eventually ended when I realized I had gone as far as the college program would take me, and applied for a transfer to the Minnesota Correctional Facility at Stillwater (MCF-STW). My transfer request was granted and I arrived at Stillwater in chains and shackles on July 17,1979 . It was rumoured that some Nebraska prison staff had placed bets on how soon I would be shipped back for misbehavior. One particular gentleman is purported to have lost a $\$ 10$ wager that I would not last a month. It is twenty years and six months later, and I am still in Minnesotaa considerably "mixed blessing."

On October 2, 1979, I was admitted into a prisoner-designed and run college program called INSIGHT, and spent the next twelve years finishing my Associate of Arts degree, and completed a B.A. in Human Services from Metro State University. In 1986 I requested and was granted another transfer to the correctional facility at Lino Lakes (MCF-LL). By then I was one course away from completing work on a masters degree from Goddard College.

My world view was gradually changing, and by 1983 it had made a 180degree shift. My only explanations for the shift in my personal philosophy are: 1) my educational pursuits had provided me with alternative views of the world and people, especially regarding human behavior and politics, and 2) I was finally growing up, and beginning to think for myself, as all my heroes and she-roes had done. It took me more than a while to catch on to that one.

Then one of the most dramatic, positive events that shaped my life occurred during the fall of 1989 while taking a break from reading Dr. Maxwell Maltz's Psycho Cybernetics. I turned on the television to a local program where a panel comprised of people from corrections, law enforcement, and the State Legislature were discussing possible ways to address the rapidly increasing juvenile crime rate in the state. Mrs. Lurline 
Baker-Kent was the panel member who said, "We can allocate all the money we want to build new prisons, and enact all the anti-crime legislation we want, but it's going to be a waste of time if we don't do something to help these kids feel good about themselves." Of course, the subject was quickly changed to something nonsensical. This is what happens when one hits upon a profundity; some politician will invariably change the subject to something irrelevant or just plain stupid. Anything to change the subject and make the issue more complicated than it is. Mrs. Baker-Kent's words resonated in my mind as I reeled from another blow of reality to my distorted thinking. Her statement shattered my social/political paradigm to make room for something more substantive and realistic. She and Dr. Maltz spoke of two terms I had heard mentioned before, but had not paid any particular attention to: self-esteem and self-image.

The next important event that revolutionized my thinking came several years later when my new supervisor, Francina Carter, mentioned how important it was to take personal responsibility, and how we need to stop blaming everyone and every circumstance for our problems, because no one forces us to act out but ourselves. In the final analysis, the decisions we make are a matter of personal choice. I gradually ceased making excuses for our savage antisocial and self-destructive behaviors and began placing the onus for pulling ourselves up from the gutter squarely on our own shoulders where it belongs.

Criminologist and best-selling author Stanton Samenow (Inside The Criminal Mind) holds that we embrace anti-social, self-destructive, and criminal behaviors out of a conscious choice, and that such behaviors can be unlearned with patience and hard work. I concur. However, considering my interests in the deeper meaning of motives behind human behaviors, Samenow's explanation did little to satisfy my question of why we make such choices.

The answer is that our attitudes and subsequent behaviors are expressions of how we feel about ourselves, in terms of our self-image, self-confidence, self-love and self-worth. And these "selves" are largely influenced by such factors as family upbringing, peer pressure, psychosis and social pathology, clinical and non-clinical depression, a need to fill a spiritual void, problemsolving abilities, anger, stress and crisis management skills, availability of role models, and meaningful connections, to name a few.

Up to this point I was confusing excuses for reasons for our problems. When making excuses, we are less likely to enter a problem-solving mode. 
And the reverse is true for reasons. Understanding this last point has made a radical (pardon the term) difference in my thinking, and in my life. This understanding has given me unlimited room to expand my consciousness, make a logical shift in my social and political paradigms, and see the world in a clearer light. The days of blaming my problems on everyone, everything and every circumstance began to evaporate. The more I learned how pervasive the issue of taking personal responsibility was in our lives, the more I have been inclined to seek logical solutions to problems, and the better I have felt about myself.

As I changed, so did peoples' attitudes toward me. Opportunities and doors opened as never before. I received a prison job that other prisoners would have killed for. I met people from the community in positions to help me. My supervisor also invited me to participate in a new institutional prerelease program, Stop the Revolving Door (SRD), which continues to operate at the Minnesota Correctional Facility at Lino Lakes. I have been facilitating self-esteem classes since the program's inception.

My interests in self-esteem gelled into the writing of two well-received booklets that addressed the needs of juvenile delinquents and at risk youth entitled The Youth Survival Guides, Parts I \& II. I did not earn much money, but circulation of the booklets gave me needed exposure as a prisoner who was involved in positive endeavors.

My most enriching and challenging educational experience to date came when I offered to hold my self-esteem classes in a treatment program called TRIAD. With several years of experience I felt the time was right for branching out to further test program content, and my abilities as a facilitator. (They do not like prisoners to refer to themselves as instructors or teachers. I am fulfilling a life-long dream, and cannot even utter the words. But I am not mad at them.) My classes begin with an hour-long talk covering my life story, including the savage beatings I endured at the heavy hands of my alcoholic father, and covers up to how I arrived at this point. One of the handout materials students receive is an eighty-seven-page workbook I wrote for the class that started seven years ago as two pages of handwritten notes. An extended two-hundred-page version will soon be published by the Graduate Group (in North Hartford, CT).

My class participants are taught that our self-confidence, self-image, and self-love shapes our thoughts and behaviors, determines in large part our worldview, and can be affected by most everything we do or that happens 
to us, because what we do is a reflection of what is going on inside us. And the three "selves" in turn determine the opinion that amounts to self-esteem. I also draw from the experiences of celebrities and public figures to show that we are all more alike than different. In the wake of the tragic shootings at Columbine High School in Littleton, Colorado, actor and martial-arts expert Chuck Norris commented, "I guarantee you those two shooters had a rock bottom self-image. If we can change the self-image, we can change the world." Following the shooting at the Jewish Community Center in Los Angeles, singer Naomi Judd said, "Do you know what the most important factor is that determines how successful we are in life? Our self-worth, because we attract that which we feel we are worthy of."

I was invited to attend a motivational program at TRIAD during the summer of 1999, and among the speakers was local Congressman Jim Ramstad, who spoke eloquently and candidly about his personal struggles with alcoholism. During conversations with fellow prisoners after the program, some were surprised to learn a man of the congressman's stature was a recovering alcoholic. I explained that we all struggle with self-esteem issues. The major difference between us and the congressman is attitude. Unfortunately, many of us still believe people are very different from one another, and that some people just woke up one day and discovered a basket full of success and prosperity on their doorstep. I believe that successful people in whatever field struggle very hard for what they have earned, and overcame tremendous roadblocks and obstacles along the way.

I also find a different application of Mrs. Baker-Kent's words: of the many needs prisoners have, among the most important is finding something in our lives that give them meaning and purpose. And if we leave prison with increased confidence in our abilities to lead productive lives; positive, successoriented self-images; a strong sense of self-love; a viable plan with a backup plan; and meaningful connections to people, places and things that support what we are doing positive for ourselves, the chances of returning to prison will be nil. The same recipe was Mrs. Baker-Kent's suggestion for keeping people out of prison in the first place.

In case you are wondering what my current list of heroes and she-roes includes, I am proud to announce that Malcolm X, Martin, and Gandhi are still on my list. But I also include such motivational speakers and authors as Iyanla Van Zant, Anthony Robbins, Earl Ofari Hutchinson, Dr. Jeffrey Lant, Dr. Phil MaGraw, Dr. Alvin Poussaint, Mahmoud El-Kati, Dennis Kimbro, 
Robert Anthony, Dottie Walters, Toby Malachi, Michael Pritchard, Joe Girard, Barbara J. Winter, Jack Canfield, Melvin Powers, Les Brown, and Harvey McKay.

And yes, even my father now.

Ed Poindexter is a prisoner peer tutor and is currently incarcerated in the Minnesota Correctional Facility at Lino Lakes. His prisoner number is 110403 , and he can be contacted at 7525 4th Avenue, Lino Lakes, Minnesota 55014, U.S.A. 